\author{
UDK 005.932:004 | DOI: https://doi.org/10.31617/zt.knute.2021(115)03 \\ JEL Classification: F01, F29, F49 \\ DUMANSKA Ilona \\ E-mail: dumanskaiy@gmail.com \\ ORCID: 0000-0003-2449-0633 \\ MATVIIETS Olha \\ E-mail: olrebak@ukr.net \\ ORCID: 0000-0001-5991-2491
}

\title{
E-LOGISTICS: DEFINITIONS, DEVELOPMENT AND CONCEPTUAL FRAMEWORK
}

The article is devoted to the study of modern logistics trends, such as e-logistics. The content of the concept of "electronic logistics» is defined and the functioning of its tools in the enterprise management system is determined. The main differences between logistics and e-logistics are determined, and the historical development of electronic logistics is investigated. The main advantages of this concept are identified and some problems in the process of functioning of electronic logistics are singled out.

Keywords: logistics, e-logistics, e-business, information technology, globalization.

Background. Informatization, electronic and international logistics business are the priority features of the current stage of globalization, which characterizes the latest stage of integration of the world economy. The essence of this stage is the spread of virtual flows of resources, which encourages the intensification of competition in global electronic markets, deepening the relationship between national economies at the level of social reproduction and the formation of integrated logistics and electronic networks.

In today's highly competitive commercial environments, the importance of fast-developing information and communication technologies (ICT) for ultimate success and, in some cases, even the survival of any logistics operation and initiatives, has been well recognized. Many business concepts would not have been successfully implemented without the aid of ICT, for example just-in-time, time compression, collaborative planning forecasting and replenishment, etc. Furthermore, contemporary global manufacturing and distribution would not be able to take place without design, sourcing, marketing, manufacturing and, ultimately, sales all being linked through the use of information technology (IT) applications. That is why, the modern logistics have become an essential tool for improving the efficiency of

(C) Dumanska I., Matviiets O., 2021 
material flow, reduce distribution costs in various industries, at the same time, the recent development of e-commerce also contributed to the expansion of the logistics market, promote the development of technologies related to logistics.

This contributed to recent technology development and the rise of e-commerce activities influenced changes in the logistics field and have «forced» companies to change their approach to logistics. Competitiveness today doesn't depend only on price but also on customer service and delivery time. This can be influenced by the implementation of modern methods in logistics. Thus, logistics service providers in the global market are looked at as business partners and the relationship with logistics service company is considered as a partnership. Because of the development in technology e-logistics concept has become more frequently used since it gives concepts for information sharing and information transparency within partners within supply chains. Thus, one of the important tasks of e-logistics is to share information with its partners and with that, it can have an influence on their competitiveness.

Analysis of recent research and publications. The issues of the impact of globalization and informatization on the logistics business were considered by domestic and foreign scientists. During some research [1], it was observed that e-logistic is one of the vital elements for the growth of the economy. It is most significant for the economy. To develop a good e-logistic system, it is mandatory to enhance e-logistic customer satisfaction level, which is a problematic area in the industry of logistics.

Emmanuel Dwamena Sasu [2] focused on understanding the impact of e-logistics capability involving the Statistical Service corporate website in his country, and its electronic data interchange (corporate email, SharePoint among others) on the performance of the National Statistical System in e-data transactions.

Ying Yua, Xin Wanga, Ray Y. Zhongb, George Q. Huanga [3] in their paper talk about the E-commerce logistics in supply chain management from a practice perspective. They proved that for the practice view of E-commerce logistics, the IT technology plays an essential role in improving the efficiency and effectiveness of supply chain management.

Aleksandar Erceg, Jovanka Damoska Sekuloska [4] in their article noted that companies need to be more customercentric and not only customer-aware. This is where e-logistics and e-SCM can help companies in creating and maintaining a competitive advantage.

G. Kanagavalli, Ramseena Azeez [5] found that E-logistics provides the idea of logistics business into the modern world through the internet and completely changes the concept of simple logistics into e-logistics. e-logistics is the most modern technology in the field of logistics which brings the whole business world into a small online e-world.

However, modern applied aspects of the implementation of e-logistics methods in enterprises need further development and improvement. 
The aim of the article is to investigate the significance of e-logistics and highlight the challenges, opportunities and future perspectives in the process of implementing the basic principles of e-logistics.

Materials and methods. Methods of analysis and synthesis, scientific generalization and comparison of data from scientific sources were used in the study. The information base for the scientific research was the works of domestic and foreign scientists and online sources of relevant thematic direction.

Results. Current trends encourage companies to use Internet tools, which allows for electronic transactions with partners in the supply chain. Constant changes in supply chain management occur due to the development of customer needs and technological capabilities of cooperating partners. Globalization, technological growth and innovative manners of economic activity, as well as increased competition and shorter product life cycle in the markets have led to a change in the size of supply chain acts: shorter lead times, global activity, greater resilience and durability. In such circumstances, one of the main tools to support business processes has become electronic data exchange over the Internet [6].

First, we note that logistics can be defined as an operational process that includes inputting, storing, transporting and distributing physical goods, while e-logistics is an Internet-enabled logistics value chain designed to offer competitive logistics services including public warehousing, contract warehousing, transportation management, distribution management, freight consolidation [7]. The terms electronic logistics, e-logistics, internetenabled logistics or e-business (e-commerce) logistics have been loosely used in both academia and practice. Some consider e-logistics as a supportive delivery process for fulfilling online e-commerce orders. Others believe that e-logistics implies the use of information and communication technology to support the provision and execution of a broad range of logistics activities. While the former narrowly defines the e-logistics utility in an online business to customer (B2C) or business to business (B2B) setting, the latter offers a broader concept focusing on utilizing ICT to manage information and information flows in supply chains or supply networks - an approach adopted by the authors of the article [8].

However, many trials have been done e-logistics term does not have one agreed definition. It is concerned that e-logistics means the use of systems, informatics tools and the Internet as communication medium to service logistic processes.

What is more there are several aspects that determine the difference between logistics and e-logistics:

- Logistics includes arranging, execution of transport and treatment of products. E-co-ordinations is at last computerizing the calculated procedure.

- In request to fulfill and address the issues of the clients, coordinations plans, executes and controls the proficient, viable stream and capacity of merchandise, benefits, and related data from the purpose of- 
inception to the point-of-utilization. E-co-ordinations is characterized as the utilization of web grounded innovation to conventional co-ordinations forms.

- The volume of business on account of conventional co-ordinations is less on the grounds that like retail locations, a lot of products are sent to lesser areas. Where as on account of e-co-ordinations, it immediately sent the lesser measure of materials to numerous clients.

- The data were gathered in customary co-ordinations through fax, desk work and Management Information System (MIS), whereas on account of e-co-ordinations the data is gathered through Integrated IS, Internet, Radio Frequency Identification (RFID) and Electronic Data Interchange (EDI). The e-co-ordinations is extra solid and quick than contrasted with customary co-ordinations.

- In e-co-ordinations the clients have high expectation about help quality and conveyance of shipments whereas on account of conventional co-ordinations speedy conveyance of items isn't at all conceivable and the client's desire were not addressed in light of the fact that now a days clients' needs faster conveyance of merchandise.

- There is less multifaceted nature in satisfying global exchange instance of conventional co-ordinations yet the intricacy is bigger to satisfying universal exchange e-co-ordinations. In e-co-ordinations it gives a possibility to put in direct requests with distributers and makers and furthermore helps in getting to more dealers all inclusive where as if there should be an occurrence of conventional co-ordinations it is chiefly finished through fax and paper functions as it is costly and acquire long time in accepting answer from makers and distributers [5].

For greater clarity, Table 1 presents the characteristics of logistics and e-logistics, which determine the main differences between these concepts.

Table 1

Difference between traditional and e-logistics [4]

\begin{tabular}{|c|c|c|}
\hline Characteristic & Traditional logistics & E-logistics \\
\hline Shipment type & Bulk & Parcel \\
\hline Customer & Strategic & Unknown \\
\hline Customer service & Reactive, Rigid & Responsive, Flexible \\
\hline Distribution model & Supply-driven push & Demand-driven pull \\
\hline Inventory / Order flow & Un-directional & Bidirectional \\
\hline Destinations & Concentrated & Highly dispersed \\
\hline Demand & Stable consistent & $\begin{array}{c}\text { Highly seasonal, } \\
\text { fragmented }\end{array}$ \\
\hline Orders & Predictable & Variable \\
\hline
\end{tabular}


In addition, presented differences between traditional logistics and e-logistics show challenges for companies which are involved in logistic processes if they want to create and maintain competitiveness in the market. E-logistics is presented as logistics concepts applied through Internet use and it means necessary processes for transferring goods which are sold online to their buyers [4].

Thus, as for logistics, the main task was to deliver products to consumers as soon as possible. Coordinating all resources, logistics must ensure compliance with service level agreements with customers. Electronic logistics is a mechanism for automating logistics processes and providing integrated end-to-end services for the execution and management of supply chains to participants in logistics processes. That is why those logistics processes that are automated by e-logistics, ensure the visibility of the supply chain and can be part of existing e-commerce systems or workflows in the enterprise [9].

Given the facts above, we think that electronic logistics is a management subsystem for forecasting, planning, decision making, coordination and control of electronic information flows using information systems, technologies, mathematical methods and models to optimize electronic information flows arising in supply chains at all levels of the management process.

The historical development of e-logistics systems is presented in Table 2. Also researchers highlight following four step changes in ICTs since the 1960s, which have had a major influence on the development of e-logistics [8]:

- connectivity (between people, applications and devices);

- capacity for distributed storage and processing of data;

- reach and range of information transmission;

- rate (speed and volume) of information transmission.

It is obvious that the growth of business process electrification has generally led to the need for online access to logistics services among suppliers and recipients in the market. Electronic data exchange allows partners to collaborate in real time and create an integrated supply chain. Reliable and efficient functioning of supply chains requires not only proper management of the physical flow of products, but also the formation of a system of information flow taking into account the functional and organizational aspects [6].

E-logistics offers access to all information just as a straight association with our vehicle and stockroom the board frameworks. E-logistics conveys rushed and simple data pretty much all procedures along the production network. There are rich capacities existing for taking care of, control and straightforwardness. We can compute cargo charges, issue transport orders, track top to bottom procedure successions in the Warehouse, locate the careful items or outright help for our co-ordinations needs, or track our shipment progressively. It makes most extreme straightforwardness. E-Logistics is characterized as «the system of mechanizing co-ordinations forms and giving a joined, start to finish satisfaction and production network the board administrations to the players of co-ordinations forms» [5]. 


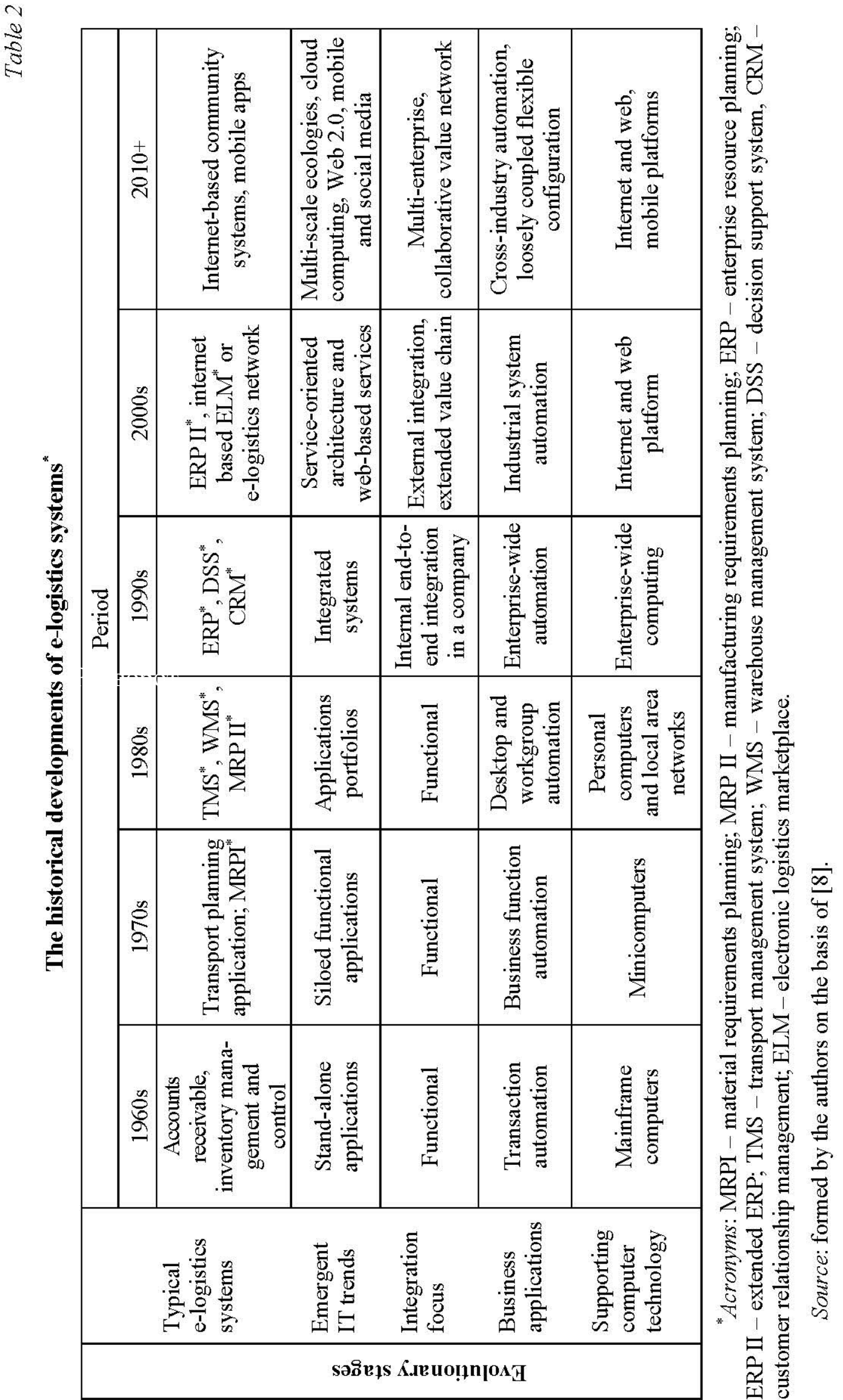


Obviously that the increased competition in all sectors due to globalization has forced the companies to reduce business costs. That is why, the companies are forming new management strategies like supply chain management and e-logistics. E-logistics means applying the concept of logistics electronically via the internet in order to conduct the business electronically.

It is also important to consider the process involved in e-logistics (Figure 1).

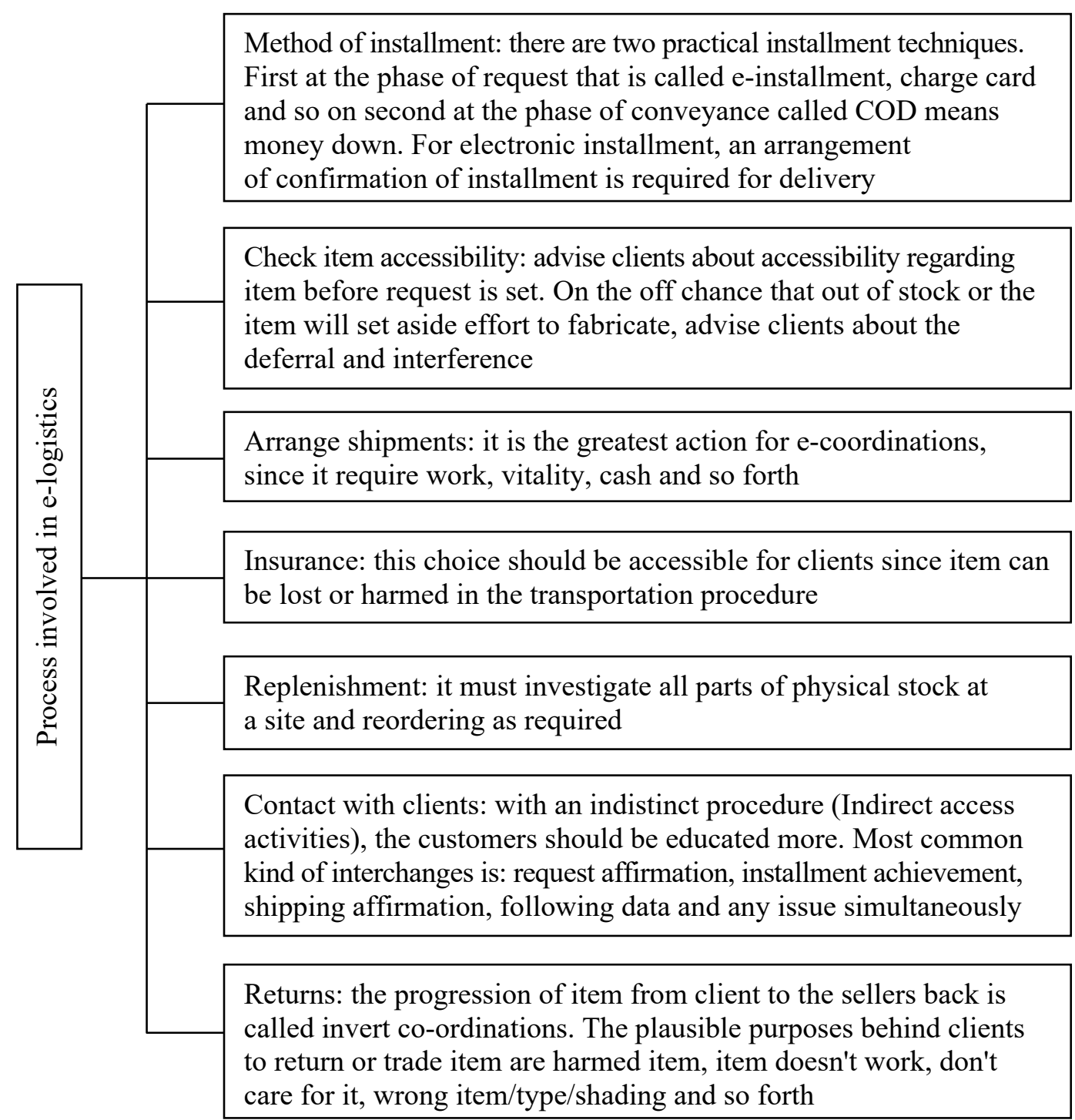

Figure 1. Process involved in e-logistics

Source: formed by the authors on the basis of [5].

In the context of the study of this issue it is appropriate to highlight the most often used tools of cooperation in the virtual scope of e-logistics (Figure 2) [6]. 


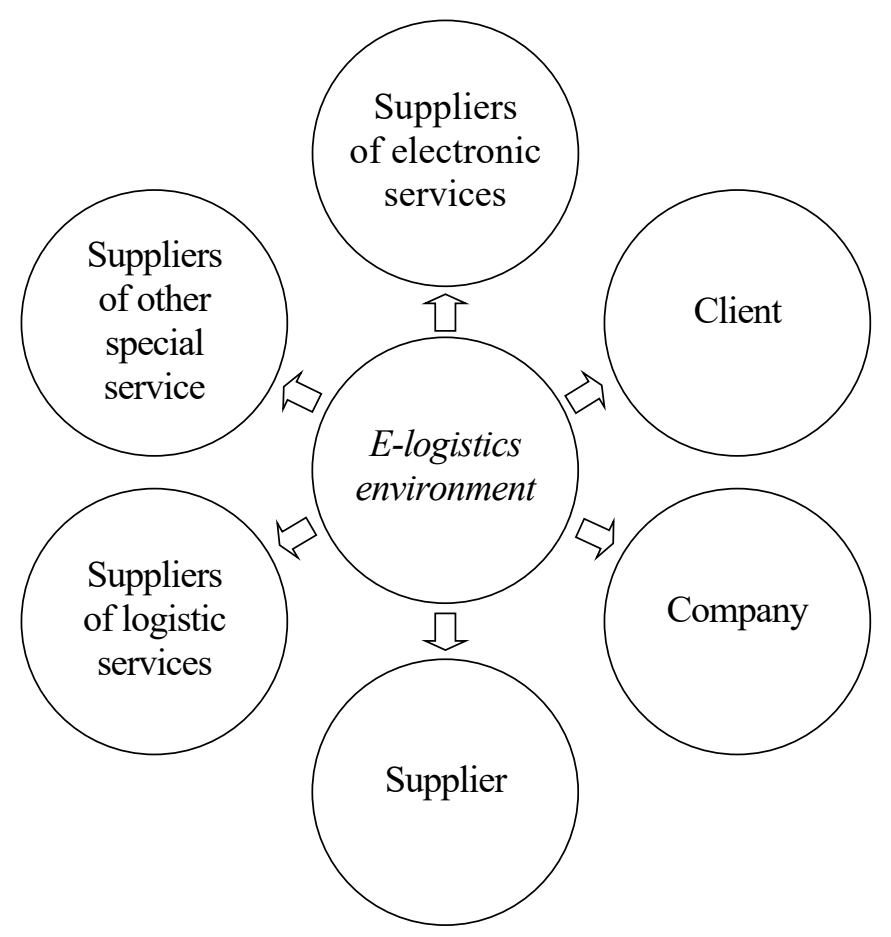

Figure 2. E-logistics environment

Source: formed by the authors on the basis of [6].

Undoubtedly, the benefits of E-business, including E-logistics, are obvious. Some of them are shown in the Figure 3.

It is no less important to single out the challenges of e-logistics in different aspects:

Security: clients need to have assurance and confidence the installment technique supplier. In some cases, we can be deceived. The honesty and notoriety of the web stores must be investigated before taking purchasing choice.

Scalability of framework: To help huge number of clients one after another, an organization should needs a well-created site. In the event that our web goal isn't adequate, it will antagonistically influence the business.

Integrity on information and framework: all the time clients need secure access and assurance of information. Except if the exchange can offer it, we should rejects web based business.

Products individuals: a large portion of the clients were select and center around items which they have to feel, attempt and so on.

Customer administration and connection issue: build steadfast association with clients is particularly fundamental. Without faithfulness from clients, we can't endure the business. Now daily the challenge in the field of e-coordinations and production network the board were likewise expanded [5]. 


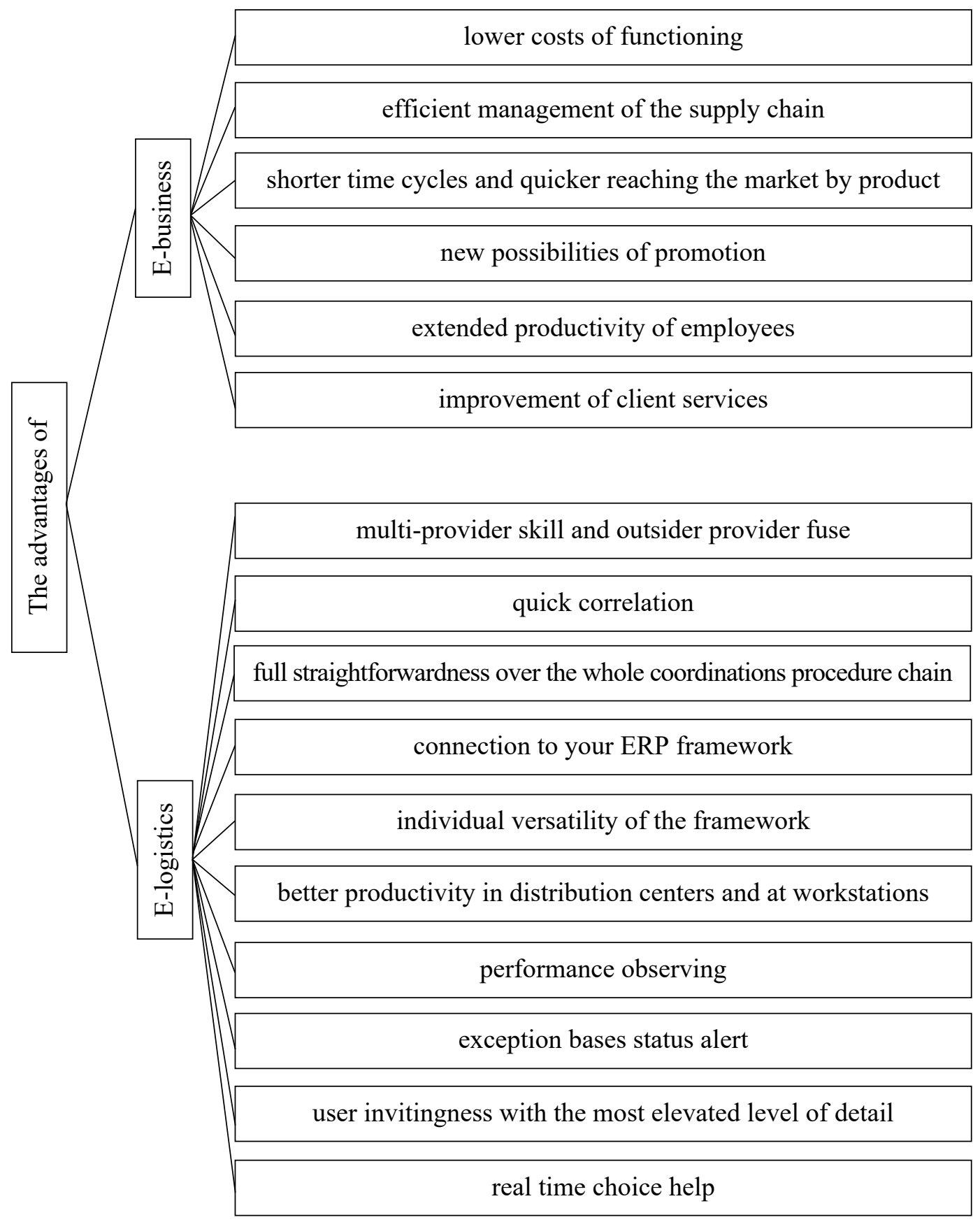

Figure 3. Main advantages of e-business and e-logistics

Sourse: formed by the authors on the basis of $[5 ; 6]$.

So, e-logistics provides the idea of logistics business into the modern world through the internet and completely changes the concept of simple logistics into e-logistics. E-logistics is the most modern technology in the field of logistics which brings the whole business world into a small online e-world. E-logistics helps in managing the new challenges in the supply chain field. The main components of the e-logistics are multi-channel 
operations, cross-border tasks, warehouse plan and inventory, planning, estimating and performance management [5].

Prospects for the development of e-logistics in Ukraine should be based on the implementation of best practices of foreign experience in logistics management. The opportunities for growth and success in this area include:

- supply chain automation will be a major trend in logistics, allowing suppliers to move more products at lower cost;

- introduction of new payment methods, which would include the use of digital payment methods and currencies;

- using big data to analyze market behavior, which will further improve the e-logistics strategy;

- the use of mobile technologies, the introduction of which adds new meaning to existing supply chain tracking systems;

- delivery process automation, which includes the use of drones and driverless vehicles to automate the delivery process, and includes the use of robotics to perform certain tasks;

- innovative delivery methods will become more important as the world becomes an era driven by e-commerce; this will speed up the delivery of more goods without the traditional restrictions of delivery confirmation;

- augmented reality and virtual reality will play an important role both in the design process and in the management of supply chain processes in the world of e-commerce.

Although it is difficult to predict the future of e-logistics, current trends clearly point to a future filled with technology-related services and efficiency gains.

Conclusion. The role of e-logistics in the modern economy is beyond doubt. In order to meet the challenges, it is necessary first of all to deal with logistical problems, which are more and more numerous. It is necessary to individualize the offer of products and services, and thereby diversify them, the customers must be provided with quick and small supplies, the business partners must have a guarantee of increasing reliability and operational flexibility, and the goods must be moved quickly and efficiently almost all over the world. All this cannot be achieved with the use of traditional methods of logistics management and, therefore, it is necessary to properly select and implement the potential benefits offered by E-logistics in the operation of a company, especially for the construction of the increasingly popular e-supply chains.

E-logistic is one of the vital elements for the growth of the economy. Information technology provides the facility to make payment electronically with no time, more secure as well as privacy which increases the satisfaction level of customers. It is quite possible to reduce traceability problems through the better information technology system. As it provides the facility to investigate the status of e-logistic goods using the Internet. By the help of information technology, it is possible to solve website related 
problems through providing all information on the website and reduce the complexity of information.

A promising area of further research is to study issues related to the implementation of modern tools of electronic logistics in the Ukrainian logistics market.

\section{REFERENCES}

1. Imran, M. et al. (2019). The contributing factors towards e-logistic customer satisfaction: a mediating role of information technology. Uncertain Supply Chain Management, 7, 63-72 [in English].

2. Dwamena Sasu, E. (2018). Understanding the Impact of E-Logistics Capability on National Statistical System E-Data Performance: A Case Study on Ghana. International Journal of Scientific and Research Publications, (Vol. 8, Issue 7), (pp. 147-150) [in English].

3. Ying, Yu (et al.). (2016). E-commerce Logistics in Supply Chain Management: Practice Perspective. Procedia CIRP, 52, 179-185 [in English].

4. Erceg, A., \& Damoska Sekuloska, J. (2019). E-logistics and e-SCM: how to increase competitiveness. LogForum, 1, 155-169 [in English].

5. Kanagavalli, G., \& Azeez, R. (2019). Logistics and E- Logistics Management: Benefits and Challenges. International Journal of Recent Technology and Engineering, (Vol. 8, Issue 4), (pp. 12804-12809) [in English].

6. Barcik, R., \& Jakubiec, M. (2012). E-logistics - aspects of functioning. Acta academica karviniensia, 12 (1), 5-12 [in English].

7. Gunasekaran, A. (et al.). (2007). Developing an E-logistics System: A case study. International Journal of Logistics: Research \& Applications, (Vol. 10), 4, 333-349 [in English].

8. Wang, Y., \& Pettit, S. (2016). E-logistics: an introduction. E-Logistics: Managing Your Digital Supply Chains for Competitive Advantage, (pp. 3-31) [in English].

9. Zhang, L. (et al.). (2001). ELPIF : An E-Logistics Processes Integration Framework Based on Web Services. Watson Research Center. Retrieved from https://www.researchgate.net/publication/2394304_ELPIF_An_E-Logistics_Processes_ Integration_Framework_Based_on_Web_Services [in English].

The article submitted to editor's office on 14.01.2021.

\section{Думанська I., Матвієць О. Е-логістика: дефініція, еволюція та концептуальна основа.}

Постановка проблеми. Інформатизація та цифровізація міжнародного логістичного бізнесу - провідні риси сучасного етапу глобалізачії, щзо характеризуе стан інтеграції світової економіки. Суть цьього етапу полягає у розповсюдженні віртуальних потоків ресурсів, щуо стимулює посилення конкуренції на світових електронних ринках, поглиблення взаємозв'язку між національними економіками на рівні сочіального відтворення та формування інтегрованої логістики й електронних мереж. Такі тенденції сприяють розвитку технологій, а зростання електронної комериї впливає 
насамперед на зміни в галузі логістики та змушує компанї̈ знаходити новий підхід до логістики загалом.

Метою статті є визначення ролі електронної логістики та дослідження проблеми, можливостей та перспектив у процесі впровадження основних принципів електронної логістики.

Матеріали та методи. У дослідженні використовувались методи аналізу та синтезу, наукового узагальнення та порівняння даних, представлених у наукових джерелах. Інформаційною базою для наукового дослідження стали прачі вітчизняних та закордонних учених, а також інтернет-джерела тематичного спрямування.

Результати дослідження. Розкрито зміст поняття «електронна логістика» та проаналізовано специфіку ї функиіонування в системі управління підприємством. Визначено основні відмінності між логістикою та електронною логістикою й досліджено історичний розвиток електронної логістики. Виокремлено основні переваги електронної логістики в сучасних умовах і деякі проблеми у прочесі ї̈ функціонування.

Висновки. Потреба запровадження електронної логістики в сучасній економіці не викликає сумнівів. Сьогодні вкрай необхідно індивідуалізувати пропозииію продуктів і послуг, у такий спосіб урізноманітнити їх, до того ж клієнтів варто забезпечити швидким зворотним зв'язком, а ділові партнери повинні мати гарантію надійності та оперативної гнучкості. Цього неможливо досягти шляхом традиційних методів управління логістикою, і тому потрібно правильно відібрати та реалізувати потениійні переваги, що пропонує електронна логістика в роботі компанії, особливо для побудови все популярнішого підходу електронних ланцюгів поставок.

Ключові слова: логістика, електронна логістика, електронний бізнес, інформаційні технології, глобалізація. 